J. Amer. Soc. Hort. Sci. 116(2):232-237. 1991.

\title{
Growth and Development of Petunia $\times$ hybrids as a Function of Temperature and Irradiance
}

\author{
M.P. Kaczperski ${ }^{1}$, W. H., Carlson, and M.G. Karlsson \\ Department of Horticulture, Michigan State University East Lansing, MI 48824-1325
}

Additional index words. day temperature, night temperature, average daily temperature

\begin{abstract}
Petunia $\times$ hybrids 'Snow Cloud' plants were grown under 25 temperature combinations ranging from 10

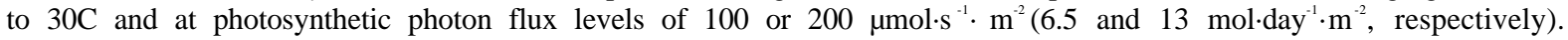
Days to flower-was a quadratic function of average temperature, with $25 \mathrm{C}$ being the optimum temperature for minimal tire-e to flower at $200 \mu \mathrm{mol} \cdot \mathrm{s}^{-1} \cdot \mathrm{m}^{-2}$. Plant height increased "linearly and average internode length increased quadratically as day temperature increased. The number of lateral shoots decreased quadratically as average temperature increased, and the average length of each shoot decreased quadratically as day temperature increased.
\end{abstract}

A fundamental objective of most commercial establishments growing bedding plants is to produce a crop that meets the quality standards of the market in the shortest time possible. Growers may manipulate irradiance, photoperiod, temperature, nutrition, and other factors alone or in combination to achieve the desired results. Thus, production time relies heavily on the past experience of the grower and the techniques used to produce the crop. Many times this method results in substandard plant quality or inefficient production methods.

The plant's response to the environment has been used to develop production strategies to increase the efficiency of producing floricultural crops (Grueber et al., 1986; Karlsson et al., 1983, 1988). Much of the research involving irradiance and temperature effects on Petunia $\times$ hybrids, a popular bedding plant (Lieberth, 1988), was conducted 15 to 30 years ago (Boodley, 1970; Carpenter and Carlson, 1974; Mastalerz, 1965; Seeley, 1955) and many of the suggested production techniques are now outdated. Only recently has interest in this area of petunia research been renewed (Armitage and Kowalski, 1982; Merritt and Kohl, 1982, 1983). The purpose of this study was to determine the influence of irradiance and temperature on the growth and development of petunia so that production strategies could be refined for the crop.

\section{Materials and Methods}

'Snow Cloud' petunia seeds were sown in no. 406 plug trays (plug size: $1.5 \times 1.5 \times 2.0 \mathrm{~cm} ; 3.0-\mathrm{ml}$ capacity) containing a commercial peat-lite mix (Michigan Peat Co., Sandusky, Mich.). Plug trays were covered with clear polyethylene and placed under constant light at $200 \mu \mathrm{mol} \cdot \mathrm{s}^{-1} \cdot \mathrm{m}^{-2}\left(17.3 \mathrm{~mol} \cdot \mathrm{day}^{-1} \cdot \mathrm{m}^{-2}\right)$ and a constant $23 \mathrm{C}$. The polyethylene was removed after 5 days and the plug trays were placed on capillary matting. Ten days after sowing, the seedlings were transplanted into $9-\mathrm{cm}$ pots (0.34 liter) filled with the same commercial peat-lite mix. Plants were irrigated as necessary to prevent water stress and fertilized with $10.7 \mathrm{~mm} \mathrm{~N}$ and $3.18 \mathrm{~mm} \mathrm{~K}$ from $\left(\mathrm{CaNO}_{3}\right)_{2}$ and $\mathrm{KNO}_{3}$ at each irrigation.

The seedlings were placed in one of five walk-in $5.85-\mathrm{m}^{2}$ growth chambers maintained with air at a constant 10, 15, 20,

Received for publication 12 June 1989. Michigan State Agricultural Experiment Station Paper no. 13029. We thank Deb Mayer and Rob Berghage for their assistance. This project was funded in part by a grant from the Fred C. Gloeckner Foundation and the Western Michigan Bedding Plant Assn. Seeds were provided by Goldsmith Seed Co. The cost of publishing this paper was defrayed in part by the payment of page charges. Under postal regulations, this paper therefore must be hereby marked advertisement solely to indicate this fact.

'Current address: Dept. of Horticulture, Univ. of Georgia, Athens, GA 30602.
25 , or 30C. Seedlings were placed at a spacing of 123.5 plants/ $\mathrm{m}^{2}$. Each chamber was maintained at an 18 -h photoperiod and divided to provide photosynthetic photon flux (PPF) levels of 100 or $200 \mu \mathrm{mol} \cdot \mathrm{s}^{-1} \cdot \mathrm{m}^{-2}\left(6.5\right.$ and $13 \mathrm{~mol} \cdot \mathrm{day}^{-1} \cdot \mathrm{m}^{-2}$, respectively). Plants were moved among growth chambers to supply a factorial combination of five day temperatures (DT), five night temperatures (NT), and two PPF levels. Changes between NT and DT corresponded with the change in photoperiod.

Leaf temperatures were measured with a Sensortek (Clifton, N. J.) BAT-12R meter and Omega (Stamford, Corm.) copperconstantan thermocouple. The difference between temperature set points and leaf temperature was $<1.5 \mathrm{C}$; temperature set points were used for data analysis. PPF was provided by a mixture of cool-white fluorescent and incandescent bulbs (input wattage 90:10, respectively), and PPF levels were adjusted by raising the lamps to maintain the proper PPF at the canopy top. PPF levels were determined with a LI-COR (Lincoln, Neb.) LI185A meter and LI-190SB quantum sensor.

Data were collected for each treatment at time of flowering. The experiment was terminated 120 days after sowing the seed,

Table 1. Mean number of days to flower for Petunia $\times$ hybrids 'Snow Cloud' in response to day and night temperatures between 10 and $30 \mathrm{C}$ and high or low irradiances $\left(13\right.$ or $6.5 \mathrm{~mol} \cdot \mathrm{day}^{-1} \cdot \mathrm{m}^{-2}$ for an 18-h photoperiod.

\begin{tabular}{|c|c|c|c|c|c|}
\hline \multicolumn{6}{|c|}{ Temp $\left({ }^{\circ} \mathrm{C}\right)$} \\
\hline & \multicolumn{5}{|c|}{ Day } \\
\hline Night & 10 & 15 & 20 & 25 & 30 \\
\hline \multicolumn{6}{|c|}{ High irradiance } \\
\hline 10 & $N^{2} \mathbf{z}$ & 77 & 60 & 51 & 49 \\
\hline 15 & 105 & 74 & 57 & 50 & 49 \\
\hline 20 & 83 & 68 & 56 & 50 & 49 \\
\hline 25 & 74 & 64 & 53 & 46 & 49 \\
\hline 30 & 66 & 57 & 51 & 46 & 52 \\
\hline \multicolumn{6}{|c|}{ Low irradiance } \\
\hline 10 & NF & 100 & 74 & 58 & 54 \\
\hline 15 & $\mathrm{NF}$ & 89 & 67 & 56 & 54 \\
\hline 20 & 101 & 81 & 67 & 55 & 52 \\
\hline 25 & 87 & 69 & 59 & 52 & 51 \\
\hline 30 & 82 & 66 & 56 & 52 & 51 \\
\hline \multicolumn{6}{|c|}{ Significance } \\
\hline NT & & $* * *$ & NT $>$ & & $* * *$ \\
\hline DT & & $* * *$ & NT $>$ & & $* * *$ \\
\hline \multirow{2}{*}{\multicolumn{2}{|c|}{ Irradiance (I) }} & $* * *$ & DT $>$ & & $* * *$ \\
\hline & & & $\mathrm{NT}$, & & $* * *$ \\
\hline
\end{tabular}

${ }^{2} \mathrm{NF}=$ Treatments did not flower within 120 days from snowing. ***Significant at $P=0.001$. 
Irradiance: $13 \mathrm{~mol} \mathrm{day}{ }^{-1} \mathrm{~m}^{-2}$

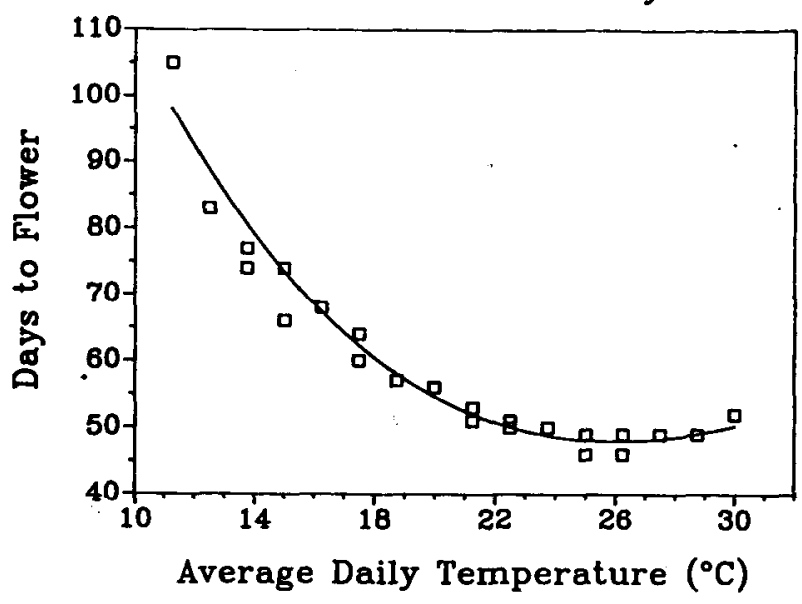

Irradiance: $6.5 \mathrm{~mol} \mathrm{day}^{-1} \mathrm{~m}^{-2}$

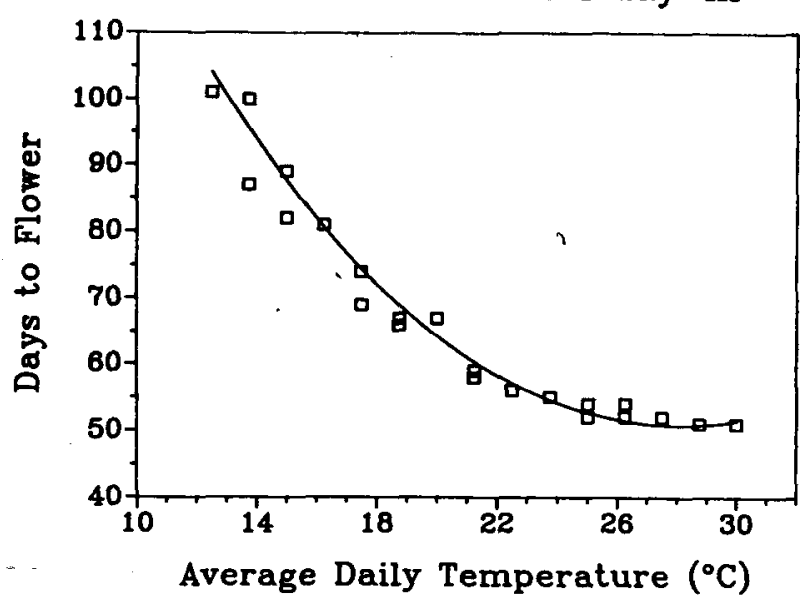

Fig. 1. Days to flower for Petunia $\times$ hybrida 'Snow Cloud' in response to average daily temperature (AVG) between 10 and 30C. (top) $13 \mathrm{~mol} \cdot \mathrm{day}^{-1} \cdot \mathrm{m}^{-2}$ [days to flower $=190.205-(11.1917 \cdot \mathrm{AVG})$ $\left.+\quad\left(0.219176 \cdot \mathrm{AVG}^{2}\right)\right], r^{2}=0.915$; (bottom) $6.5 \mathrm{~mol} \cdot \mathrm{day}^{-1} \cdot \mathrm{m}^{-2}$ [days to flower $\left.=212.741-(11.7045 \cdot \mathrm{AVG})+\left(0.211953 \cdot \mathrm{AVG}^{2}\right)\right]$, $r^{2}=0.937$.

at which time data were collected on remaining plants not yet flowering. Data collected included days from sowing to flower, plant height, average internode length, number of lateral shoots, and average lateral shoot length. A plant was considered in flower when the outer edge of the corolla reflexed perpendicularly to the corolla tube. Plant height was measured from the soil line to the top of the main stem. Average internode length was determined for the internodes on the main stem and did not include any lateral shoots. Lateral shoots that had attained a minimum length of $4 \mathrm{~mm}$ were counted and measured from the point of attachment to the main stem to the end of the stem of the shoot.

\section{Results and Discussion}

Plants grown at a constant $10 \mathrm{C}$ at either irradiance and those grown at $15 \mathrm{C}$ NT and $10 \mathrm{C}$ DT at $6.5 \mathrm{~mol} \cdot \mathrm{day}^{-1} \cdot \mathrm{m}^{-2} \mathrm{did}$ not flower within 120 days from sowing (Table 1). Days to flower was determined to be a quadratic function of average tempera-
Irradiance: $13 \mathrm{~mol} \cdot \mathrm{day}^{-1} \cdot \mathrm{m}^{-1}$

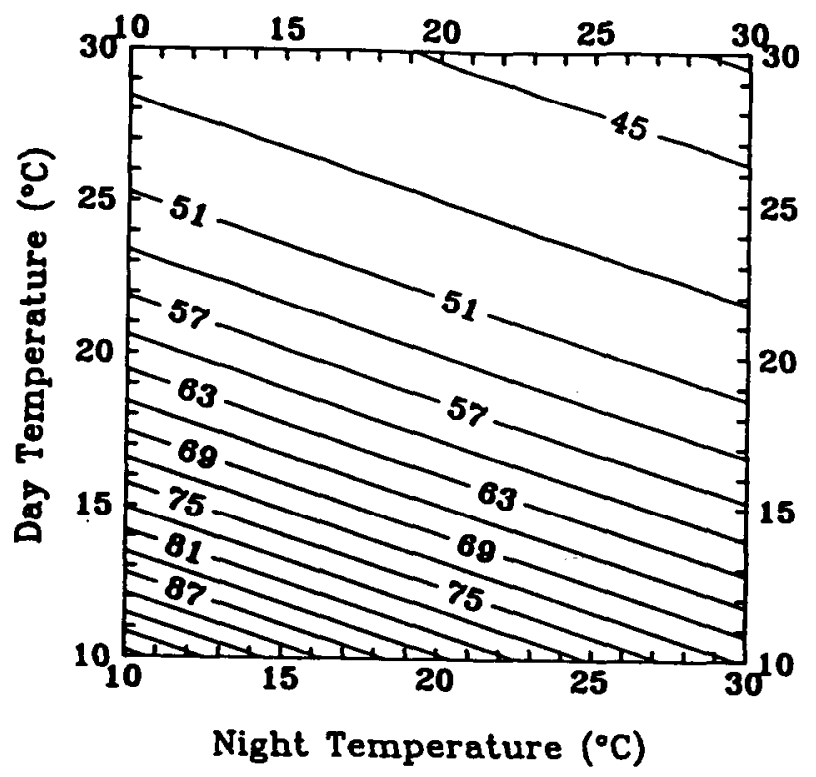

Irradiance: $6.5 \mathrm{~mol} \cdot \mathrm{day}^{-1} \cdot \mathrm{m}^{-8}$

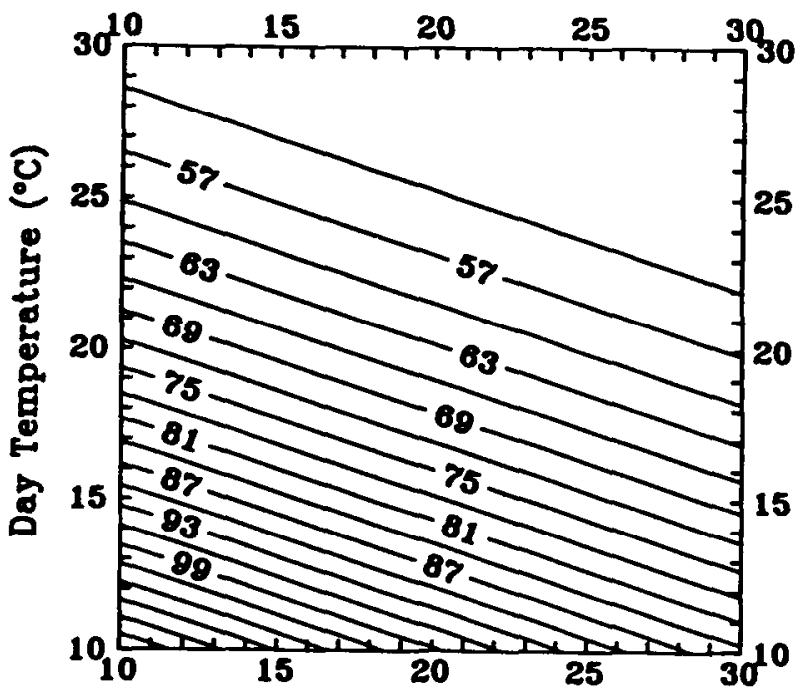

Fig. 2. [sopleth plots of days to flower for varying combinations of night and day temperature between 10 and 36C for Petunia $\times$ hybrida 'Snow Cloud' at: (top) $13 \mathrm{~mol} \cdot \mathrm{day}^{-1} \cdot \mathrm{m}^{-2}$ and (bottom) 6.5 $\mathrm{mol} \cdot \mathrm{day}^{-1} \cdot \mathrm{m}^{-2}$.

ture (AVG) for each irradiance (Fig. 1). As AVG increased, days to flower decreased. Plants grown under $13 \mathrm{~mol} \cdot \mathrm{day}^{-1} \cdot \mathrm{m}^{-2}$ flowered 3 to 23 days before their respective counterparts at the lower irradiance, except at the two highest AVG (25C NT/30C DT and constant $30 \mathrm{C}$ ), which showed no significant difference in time to flower between the two irradiance levels. Irradiance had more of an effect in reducing time to flower at the lower AVG than at the higher AVG. Isopleth plots were developed from the equations to show the response of time to flower to varying NT and DT at an 18-h photoperiod (Fig. 2). 
Table 2. Mean plant height (in centimeters) for Petunia x hybrids 'Snow Cloud' in response to day and night temperatures between 10 and $30 \mathrm{C}$ and high or low irradiances $\left(13\right.$ or $\left.6.5 \mathrm{~mol} \cdot \mathrm{day}^{-1} \cdot \mathrm{m}^{-2}\right)$ for an 18 -h photoperiod.

\begin{tabular}{|c|c|c|c|c|c|}
\hline \multicolumn{6}{|c|}{ Temp $\left({ }^{\circ} \mathrm{C}\right)$} \\
\hline \multirow[b]{2}{*}{ Night } & \multicolumn{5}{|c|}{ Day } \\
\hline & 10 & 15 & 20 & 25 & 30 \\
\hline \multicolumn{6}{|c|}{ High irradiance } \\
\hline 10 & 11.3 & 12.5 & 17.5 & 21.6 & 21.6 \\
\hline 15 & 11.7 & 12.2 & 15.2 & 19.4 & 22.9 \\
\hline 20 & - 11.2 & 12.0 & 25.4 & 22.1 & 23.0 \\
\hline 25 & 12.7 & 14.2 & 19.1 & 19.5 & 20.8 \\
\hline 30 & 13.3 & 13.8 & 19.4 & 21.5 & 25.3 \\
\hline \multicolumn{6}{|c|}{ Low irradiance } \\
\hline 10 & 11.8 & 17.8 & 20.6 & 23.3 & 27.1 \\
\hline 15 & 12.6 & 17.9 & 21.3 & 27.6 & 26.7 \\
\hline 20 & 14.6 & 16.9 & 27.0 & 25.2 & 28.6 \\
\hline 25 & 16.6 & 16.3 & 21.6 & 26.1 & 27.5 \\
\hline 30 & 13.5 & 16.4 & 23.3 & 25.2 & 37.5 \\
\hline \multicolumn{6}{|c|}{ Significance } \\
\hline NT & & $* * *$ & NT $>$ & & $* * *$ \\
\hline DT & & $* * *$ & NT $\succ$ & & NS \\
\hline \multirow{2}{*}{\multicolumn{2}{|c|}{ Irradiance (I) }} & $* * *$ & DT $>$ & & $* * *$ \\
\hline & & & NT $>$ & $\times I$ & $* * *$ \\
\hline
\end{tabular}

NS,***Nonsignificant or significant at $P=0.001$, respectively.

Increasing air temperature has long been known to decrease time to flower in petunia (Seeley, 1955). It has also been shown that increasing the soil temperature while maintaining commercial production air temperatures would produce similar results (Merritt and Kohl, 1982). Plants in this study, grown at 13.5 mol.day ${ }^{-1} \mathrm{~m}^{-2}$, showed a significant decrease in flowering time as the average air temperature approached $25 \mathrm{C}$, with higher temperatures slightly delaying the crop. This delay may have been due, at least in part, to the increased bud abortion experienced at the higher average temperature (data not reported). Similar bud abortion was found at the lower irradiance also.

An irradiance of 13 rather than $6.5 \mathrm{~mol} \cdot \mathrm{day}^{-1} \cdot \mathrm{m}^{-2}$ decreased time to flower in petunia (Table 1) by up to 3 weeks. High intensities of fluorescent lights $\left(287 \mu \mathrm{mol} \cdot \mathrm{s}^{-1} \cdot \mathrm{m}^{-2}\right)$ used to supplement natural light conditions when growing petunias were shown to decrease time to flower by up to 12 days when compared to plants receiving low-intensity incandescent lighting to extend the photoperiod (Carpenter and Beck, 1973). In our study, plants flowered in 67 days when grown with air at a mean of $20 \mathrm{C}$ and at an irradiance of $6.5 \mathrm{~mol} \cdot \mathrm{day}^{-1} \cdot \mathrm{m}^{-2}$. However, when the intensity was doubled, the plants flowered in only 56 days. At the higher irradiance, the average temperature could be lowered to $15 \mathrm{C}$ and plants still would flower at the same time as those grown at 20C at the lower irradiance. The plants could be held at a high NT with little heating during the day. This procedure would result in fuel savings for commercial applications using heat blankets, since only the small area under the blanket would be raised to the higher temperature at night. Time to flower would not increase.

Plant height (Table 2, Fig. 3) increased as DT increased or as irradiance decreased. Plant height was influenced more by low irradiance at 30C DT than at 10C DT. Plants grown at 10C DT and an irradiance of $13 \mathrm{~mol} \cdot \mathrm{day}^{-1} \cdot \mathrm{m}^{-2}$ were similar in height to those grown at the lower irradiance and corresponding NT. However, as DT increased, the difference in plant height at the same NT/DT combination increased when the two irradiances were compared (Fig. 4). Plants grown under 13
Irradiance: $13 \mathrm{~mol} \cdot \mathrm{day}^{-1} \cdot \mathrm{m}^{-2}$

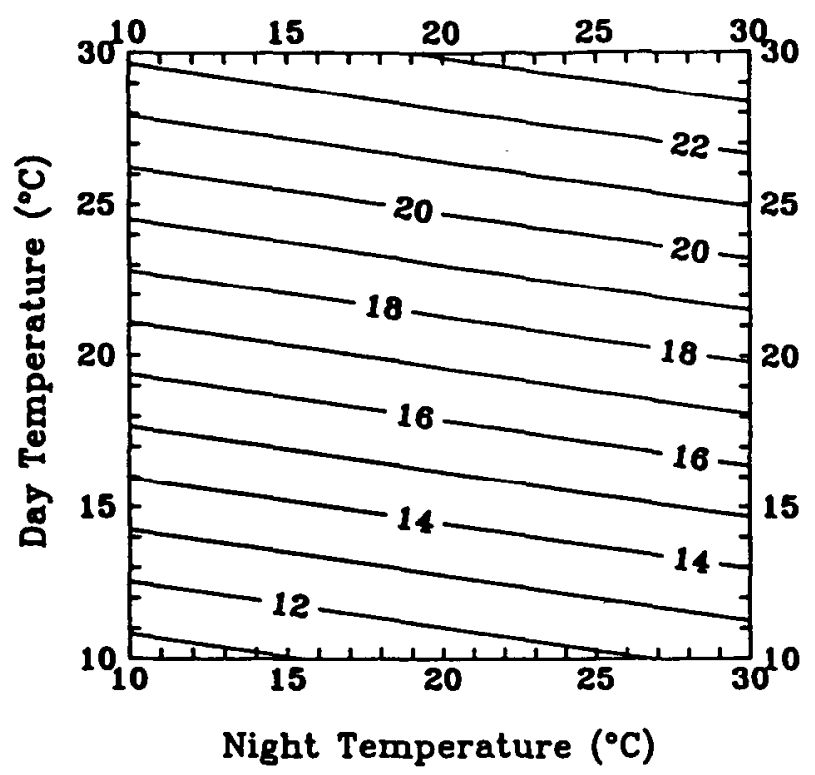

Irradiance: $6.5 \mathrm{~mol} \cdot \mathrm{day}^{-1} \cdot \mathrm{m}^{-8}$

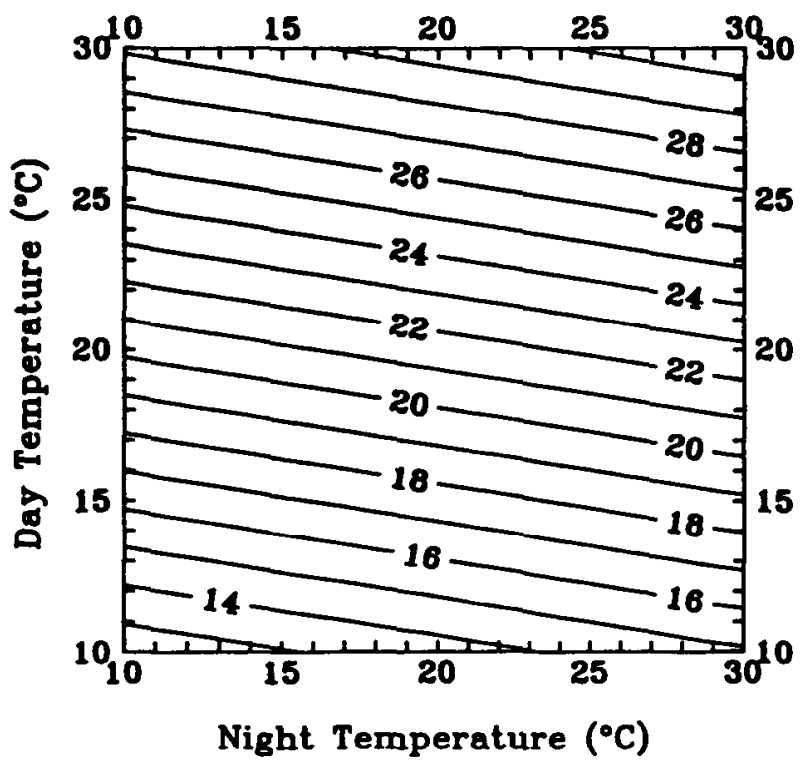

Fig. 3. Isopleth plots of plant height (in centimeters) for varying combinations of night and day temperature between 10 and $30 \mathrm{C}$ for Petunia $\times$ kybrida 'Snow Cloud' at: (top) $13 \mathrm{~mol} \cdot \mathrm{day}^{-1} \cdot \mathrm{m}^{-2}$ [plant height $=3.78643+(0.3204 \cdot \mathrm{DT})+(0.35232 \cdot \mathrm{AVG})], r^{2}=0.750$ and (bottom) 6.5 mol.day ${ }^{-1} \cdot \mathrm{m}^{-2}$ (plant height $=3.01463+$ $(0.40296 \cdot \mathrm{DT})+(0.5216 \cdot \mathrm{AVG})], r^{2}=0.810$

mol.day ${ }^{-1} \cdot \mathrm{m}^{-2}$ at $30 \mathrm{C}$ DT were up to $6 \mathrm{~cm}$ shorter than plants grown under $6.5 \mathrm{~mol} \cdot \mathrm{day}^{-1} \cdot \mathrm{m}^{-2}$ and $30 \mathrm{C}$ DT. Plants grown at a constant $20 \mathrm{C}$ at either irradiance were much taller than expected, based on the data collected from plants from the other treatments. Since this response could not be reproduced in subsequent trials, we considered it anomalous and data from these treatments were not used in data analysis for plant height or average internode length. 
Night Temperature: $30^{\circ} \mathrm{C}$

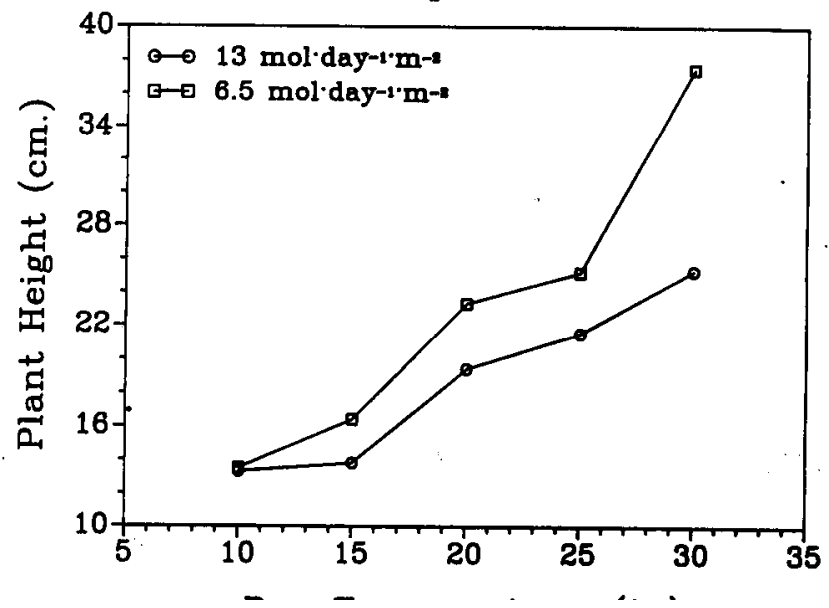

Fig. 4. Plant height for Petunia $\times$ hybrids 'Snow Cloud' at 30C NT and DT between 10 and $30 \mathrm{C}$ at irradiances of 13 and 6.5 $\mathrm{mol} \cdot \mathrm{day}^{-1} \cdot \mathrm{m}^{-2}$.

Table 3. Mean average internode length $(\mathrm{cm})$ for Petunia $\times$ hybrida 'Snow Cloud' in response to day and night temperatures between 10 and $30 \mathrm{C}$ and high or low irradiances $\left(13\right.$ or $6.5 \mathrm{~mol} \cdot \mathrm{day}^{-1} \cdot \mathrm{m}^{-2}$ ) for an 18 -h photoperiod.

\begin{tabular}{|c|c|c|c|c|c|}
\hline \multicolumn{6}{|c|}{ Temp $\left({ }^{\circ} \mathrm{C}\right)$} \\
\hline \multirow[b]{2}{*}{ Night } & \multicolumn{5}{|c|}{ Day } \\
\hline & 10 & 15 & 20 & 25 & 30 \\
\hline \multicolumn{6}{|c|}{ High irradiance } \\
\hline 10 & 0.6 & 0.6 & 1.0 & 1.1 & 1.2 \\
\hline 15 & 0.6 & 0.9 & 0.8 & 1.1 & 1.3 \\
\hline 20 & 0.6 & 0.7 & 1.4 & 1.2 & 1.3 \\
\hline 25 & 0.6 & 0.7 & 1.0 & 1.0 & 1.1 \\
\hline 30 & 0.7 & 0.7 & 1.1 & 1.3 & 1.2 \\
\hline \multicolumn{6}{|c|}{ Low irradiance } \\
\hline 10 & 0.7 & 1.0 & 1.2 & 1.4 & 1.5 \\
\hline 15 & 0.7 & 1.0 & 1.3 & 1.6 & 1.5 \\
\hline 20 & 0.8 & 1.0 & 1.6 & 1.5 & 1.5 \\
\hline 25 & 0.9 & $0.9^{\circ}$ & 1.2 & 1.5 & 1.5 \\
\hline 30 & 0.8 & 0.9 & 1.4 & 1.4 & 1.9 \\
\hline \multicolumn{6}{|c|}{ Significance } \\
\hline \multicolumn{2}{|c|}{ NT } & $*$ & \multicolumn{2}{|c|}{$\mathrm{NT} \times \mathrm{DT}$} & * \\
\hline \multicolumn{2}{|c|}{ DT } & $* * *$ & \multicolumn{2}{|c|}{$\mathrm{NT} \times \mathrm{I}$} & NS \\
\hline \multirow{2}{*}{\multicolumn{2}{|c|}{ Irradiance (I) }} & $* * *$ & \multicolumn{2}{|c|}{ DT $\times I$} & $* * *$ \\
\hline & & & $\mathrm{NT}$ & $\times I$ & $* * *$ \\
\hline
\end{tabular}

$\overline{\text { NS,*,***Nonsignificant or significant at } P=0.05 \text { or } 0.001 \text {, respec- }}$ tivelv.

Plant height was dependent on internode length, since all plants flowered with a similar number of nodes on the main stem. The effects of DT and irradiance on average internode length were similar to their effects on plant height. As DT increased, average internode length increased significantly (Table 3). Likewise, plants at the lower irradiance had longer average internode lengths than plants at the higher irradiance. The effect of NT was less significant than either DT or irradiance (Fig. 5).

Krizek et al. (1972) reported that increasing both DT and NT increased plant height in petunia seedlings. However, they only used three temperature regimes in which an increase in NT accompanied an increase in DT. They did not discuss separate effects of NT and DT, just the combined effects.

The difference between day temperature and night temperature (DIF) has been shown to influence internode length and
Irradiance: $13 \mathrm{~mol} \cdot \mathrm{day}^{-1} \cdot \mathrm{m}^{-2}$
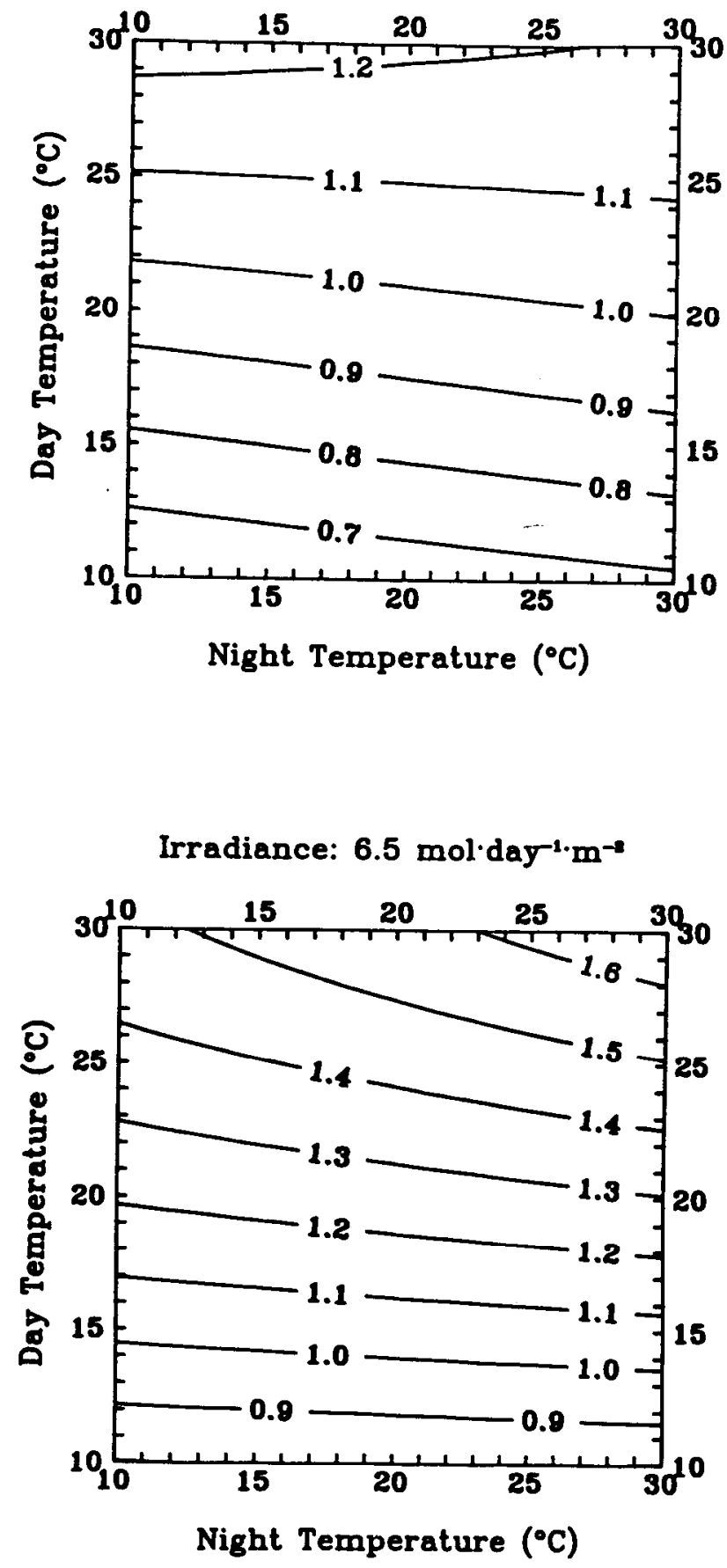

Fig. 5. Isopleth plots of average internode length (in centimeters) for varying combinations of night and day temperatures between 10 and 30C for Petunia $\times$ hybrida 'Snow Cloud' at: (top) $13 \mathrm{~mol} \cdot \mathrm{day}^{-1} \cdot \mathrm{m}^{-2}$ [average internode length $=0.143507+(0.037663 \cdot \mathrm{DT})+$ $\left.(0.00063527 \cdot \mathrm{DT} \cdot \mathrm{NT}) \quad-\quad\left(0.000023821 \cdot \mathrm{NT} \cdot \mathrm{DT}^{2}\right)\right], r^{2}=0.733$; (bottom) $6.5 \mathrm{~mol} \cdot \mathrm{day}^{-1} \cdot \mathrm{m}^{-2}$ [average internode length $=0.13144$ $\left.+(0.069617 \cdot \mathrm{DT})-\left(0.0009204 \cdot \mathrm{DT}^{2}\right)+\left(0.000011519 \cdot \mathrm{NT} \cdot \mathrm{DT}^{2}\right)\right]$, $r^{2}=0.809$.

plant height (Erwin et al., 1989). Internode length increases as DIF increases. DIF did not have as great an effect in this experiment as has been seen in other plants. However, the 18-h photoperiod may have decreased the effect of DIF, and DIF might have been more apparent if a shorter photoperiod had been selected. 

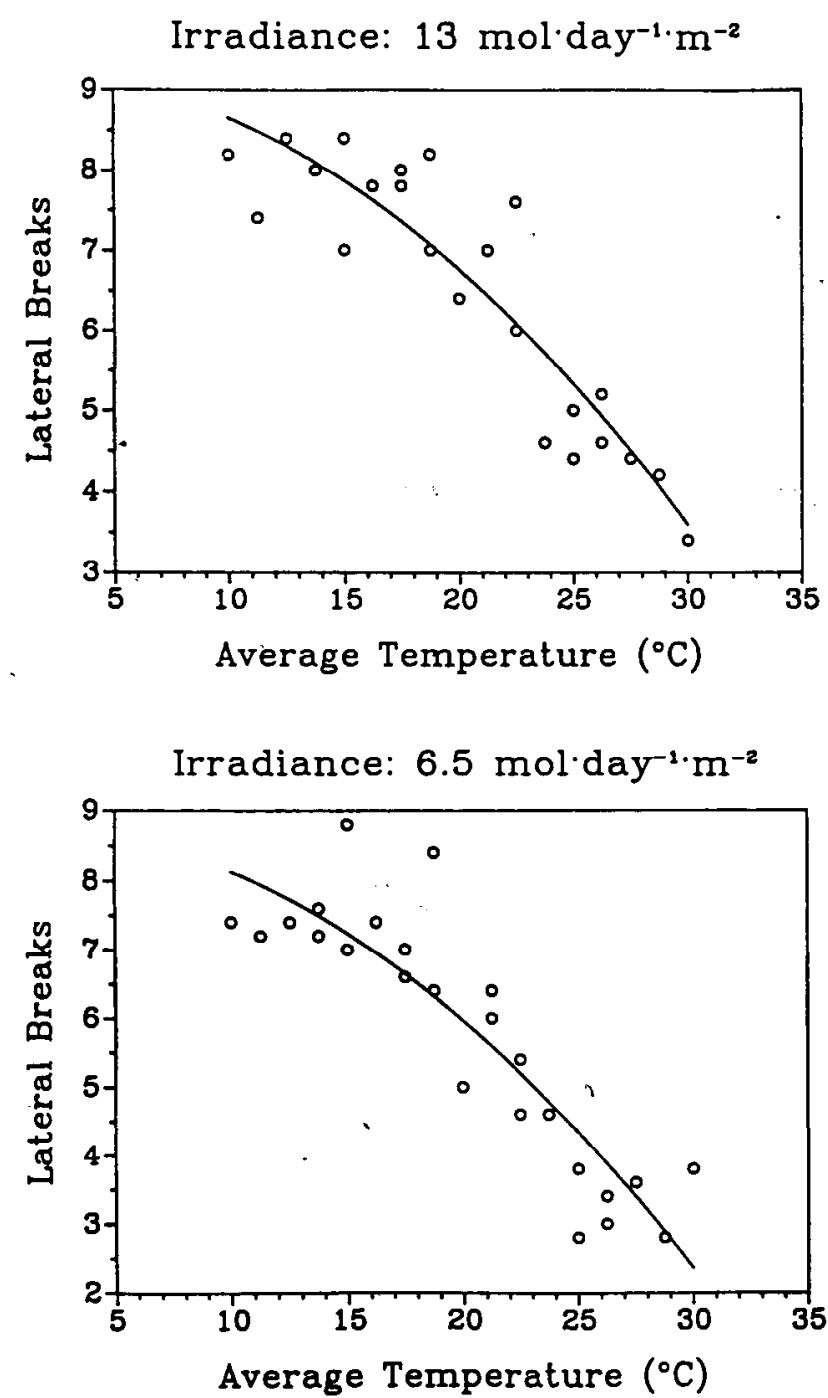

Fig.6. Lateral shoots formed by Petunia $\times$ kybrida 'Snow Cloud' in response to average daily temperature (AVG) between 10 and 30C for (top) $13 \mathrm{~mol} \cdot \mathrm{day}^{-1} \cdot \mathrm{m}^{-2}$ [number of shoots $=9.29607-$ $\left.\left(0.00634 \cdot \mathrm{AVG}^{2}\right)\right], r^{2}=0.837$; (bottom) $6.5 \mathrm{~mol} \cdot \mathrm{day}^{-1} \cdot \mathrm{m}^{-2}$ (number of shoots $\left.=8.85987-\left(0.00723 \cdot \mathrm{AVG}^{2}\right)\right], r^{2}=0.801$.

The number of lateral shoots formed by the plants was a function of average temperature (Table 4). Plants formed a similar number of lateral shoots at both irradiances. As average temperature increased, the number of lateral shoots decreased (Fig. 6). The average length of each lateral shoot varied widely within each plant. However, average length was strongly influenced by day temperature (Table 5) —as day temperature increased, the average length decreased. Night temperature had no effect.

Previous work showed that higher temperatures decreased lateral branching in petunia (Carpenter, 1974; Carpenter and Carlson, 1974; Piringer and Cathey, 1960), similar to the results found in this study. Petunia and other crops have also shown increased lateral branching when light intensity increased (Carpenter, 1974; Erickson et al., 1980). An increase in lateral branching under a higher intensity was not evident from our data. However, the higher intensity used in this study (200 $\mu \mathrm{mol} \cdot \mathrm{s}^{-1} \cdot \mathrm{m}^{-2}$ ) was not as high as intensities used in other experiments (533 $\left.\mu \mathrm{mol} \cdot \mathrm{s}^{-1} \cdot \mathrm{m}^{-2}\right)$ (Carpenter, 1974).

Plant quality is the main underlying factor to consider when
Table 4. Mean lateral shoot number for Petunia $\times$ hybrida 'Snow Cloud' in response to day and night temperatures between 10 and $30 \mathrm{C}$ and high or low irradiances (13 or $6.5 \mathrm{~mol} \cdot \mathrm{day}^{-1} \cdot \mathrm{m}^{-2}$ ) for an 18-h photoperiod.

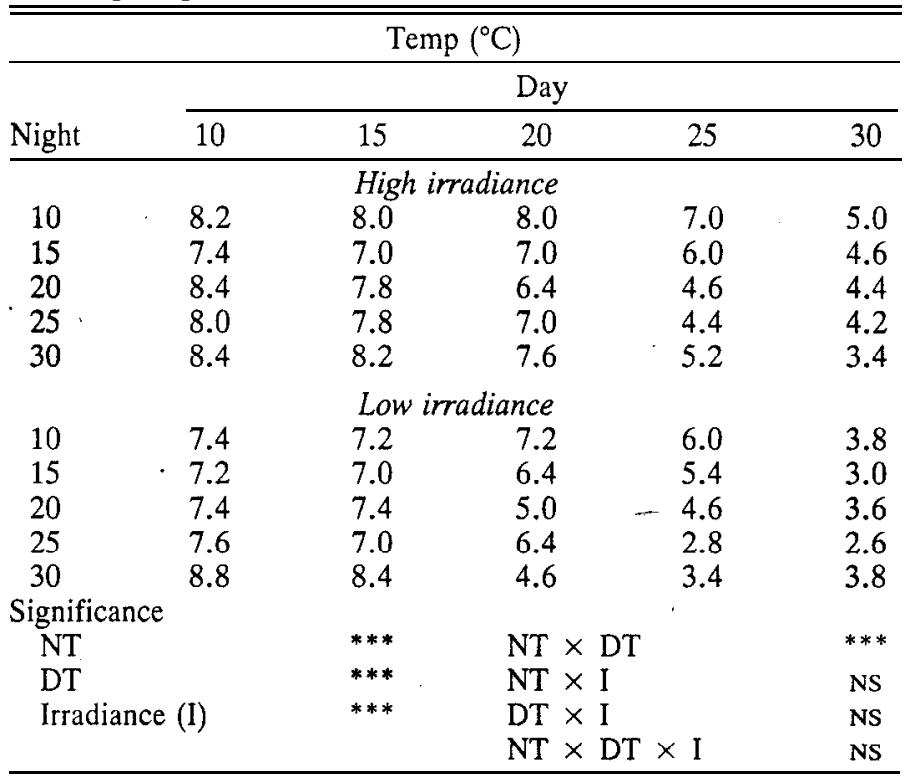

NS,***Nonsignificant or significant at $P=0.001$, respectively.

Table 5. Mean lateral shoot length (in centimeters) for Petunia $\times$ hybrida 'Snow Cloud' in response to day and night temperatures between 10 and $30 \mathrm{C}$ and high and low irradiances (13 or 6.5 $\mathrm{mol} \cdot \mathrm{day}^{-1} \cdot \mathrm{m}^{-2}$ ) for an 18 -h photoperiod.

\begin{tabular}{|c|c|c|c|c|c|}
\hline \multicolumn{6}{|c|}{ Temp $\left({ }^{\circ} \mathrm{C}\right)$} \\
\hline \multirow[b]{2}{*}{ Night } & \multicolumn{5}{|c|}{ Day } \\
\hline & 10 & 15 & 20 & 25 & 30 \\
\hline \multicolumn{6}{|c|}{ High irradiance } \\
\hline 10 & 8.1 & 8.2 & 6.0 & 2.7 & 1.3 \\
\hline 15 & 7.7 & 8.2 & 7.0 & 2.4 & 1.8 \\
\hline 20 & 8.7 & 7.4 & 4.1 & 2.3 & 0.8 \\
\hline 25 & 8.4 & 8.3 & 7.2 & 2.6 & 1.2 \\
\hline 30 & 9.7 & 7.7 & 6.5 & 2.0 & 0.9 \\
\hline \multicolumn{6}{|c|}{ Low irradiance } \\
\hline 10 & 8.1 & 8.1 & 6.5 & 2.4 & 0.8 \\
\hline 15 & 7.2 & 5.6 & 4.5 & 1.7 & 0.6 \\
\hline 20 & 8.1 & 7.2 & 3.2 & 2.1 & 1.9 \\
\hline 25 & 9.6 & 7.8 & 3.7 & 1.7 & 1.3 \\
\hline 30 & 7.4 & 5.6 & 4.0 & 3.0 & 1.0 \\
\hline \multicolumn{6}{|c|}{ Significance } \\
\hline NT & & NS & NT & & NS \\
\hline DT & & $* * *$ & NT & & NS \\
\hline \multirow{2}{*}{\multicolumn{2}{|c|}{ Irradiance (I) }} & $*$ & DT & & NS \\
\hline & & & NT & $\times 1$ & NS \\
\hline
\end{tabular}

NS,*,***Nonsignificant or significant at $P=0.005$ or 0.001 , respectively.

selecting combinations of irradiance, day temperatures, and night temperatures for forming plant production strategies for petunia. Plant growth can be increased by raising temperatures (Krizek et al, 1972), but this increased growth rate will also result in lower plant quality by increasing plant height and reducing lateral branching (Merritt and Kohl, 1982; Piringer and Cathey, 1960). Lateral branching and reduced plant height, resulting in increased quality, can be obtained by lowering the growing temperatures. However, this strategy will result in a corresponding delay in time to flower and an extended production period. 
Individual growers must first determine the quality their particular market will demand. Only then can a proper selection of combinations of temperature and irradiance be made to produce petunias of desired quality in the shortest time.

\section{Literature Cited}

Armitage, A.M. and T. Kowalski. 1982. Effects of light intensity and air temperature in simulated post production environment on Petunia hybrida Vilm. J. Amer. Soc. Hort. Sci. 108(1):115-118.

Boodley, J.W. 1970. Influence of container size on petunia growth. New York State Floral Ind. Bul. 1. p. 4-5.

Carpenter, W.J. 1974. High intensity lighting in the greenhouse. Res. Rpt. 255. Michigan State Univ., East Lansing.

Carpenter, W.J. and G.R. Beck. 1973. High intensity supplementary lighting of bedding plants after transplanting, HortScience 8(6):482483.

Carpenter, W.J. and W.H. Carlson. 1974. Comparison of photoperiodic and high intensity lighting on the growth and flowering of Petunia $\times$ hybrida Vilm. The Michigan Florist 52:16-24.

Erickson, V. L., A. Armitage, W.H. Carlson, and R.M. Miranda. 1980. The effect of cumulative photosynthetically active radiation on the growth and flowering of the seedling geranium, Pelargonium $\times$ hortorum 'Bailey'. HortScience 15(6):815-817.

Erwin, J. E., R.D, Heins, and M.G. Karlsson, 1989. Thermomorphogenesis in Lilium longiflorum., Amer. J. Bet. 76(1):47-52.

Grueber, K. L., W.E. Healy, H.B. Pemberton, and H.F. Wilkins. 1986.
Easter lily leaf unfolding rate as influenced by temperature. Minnesota State Florists Bul. 35(6):1-4.

Karlsson, M., R.D. Heins, and W.H. Carlson. 1983. Development of environmental strategies based on plant growth models. Acta Hort. 147:153-160.

Karlsson, M. G., R.D. Heins, and J.E. Erwin. 1988. Quantizing temperature-controlled leaf unfolding rates in 'Nellie White' Easter lily. J. Amer. Soc. Hort. Sci. 113(1):70-74.

Krizek, D. T., H.H. Klueter, and W.A. Bailey. 1972. Effects of day and night temperature and type of container on the growth of $F_{1}$ hybrid annuals in controlled environments. Amer. J. Bet. 59(3):284289.

Lieberth, J.A. 1988. It was a very good year. Greenhouse Grower 6(10):30-32.

Mastalerz, J.W. 1965. Constant vs alternating temperatures compared for best plant growth. Bul. Pennsylvania Flower Growers 61:5.

Merritt, R.H. and H.C. Kohl, Jr. 1982. Effect of root temperature and photoperiod on growth and crop productivity efficiency of petunia. J. Amer. Soc. Hort. Sci. 107(6):997-1000.

Merritt, R.H. and H.C. Kohl, Jr. 1983. Crop productivity efficiency of petunias in the greenhouse. J. Amer. Soc. Hort. Sci. 108(4):544548 .

Piringer, A.A. and H.M. Cathey. 1960. Effect of photoperiod, kind of supplemental light and temperature on the growth and flowering of petunia plants. Proc. Amer. Soc. Hort. Sci. 76:649-660.

Seeley, J.G. 1955. Petunias for sale 8 weeks after potting. Bul. Pennsylvania Flower Growers. 51:1, 4-7. 